\title{
Critical Discourse Analysis: The Negative Representation of the French President in France's English Online News
}

\author{
Yulia Anggraeni*, Elvi Citraresmana, \& Eko Wahyu Koeshandoyo \\ Universitas Padjajaran, Bandung, Indonesia \\ *yulia19003@mail.unpad.ac.id
}

\section{ARTICLE HISTORY \\ Received : 18 September 2021 \\ Revised : 13 November 2021 \\ Accepted : 23 November 2021}

\section{KEYWORDS}

Critical Discourse Analysis

Discursive Strategy

French President Emmanuel Macron

Negative Representation

Nomination Strategy

Predication Strategy

\begin{abstract}
There is a scarcity of Critical Discourse Analysis (CDA) studies on the representation of social actors in news media, thus this study addressed this research gap by analysing the way news represented the French President Emmanuel Macron, regarding his controversial support of Samuel Paty, a history teacher in France who was murdered because he showed a cartoon of Prophet Muhammad in his class. This research aims to see the representation of Emmanuel Macron from the perspective of the French media, The Connexion France, which published their news in English language online to reach world-wide audience. Four articles of the news were purposively selected for this CDA study, which were published from October 18 until November 1, 2020. The French President's representation was analysed with the nomination and predication strategies. Results showed that the Connexion France uses four nomination strategies to refer Emmanuel Macron. The professional anthroponyms refer to Emmanual Macron as "the President", proper names as "Emmanuel Macron" to be the centre of the discourse, synecdoche as "Emmanuel Macron", and deixis as "he" to avoid repetition the subject of the text. Two predication strategies were also used, the explicit predicate of how the President "has promised" action against Islamists and presupposition from the way the news linked pictures of boycotted French supermarket products with the President. This research provides a take on fresh news with CDA and can beneficial for the students who learn English by showing how the media uses language for political figures.
\end{abstract}

\section{Introduction}

In October 2020, French President Emmanuel Macron made a controversial speech in tribute to a history teacher in France, Samuel Paty, who was murdered for showing cartoons or caricatures of the Prophet Muhammad in his class. Because of this, Paty was eventually executed by the suspected killer, Abdoullakh Abouyezidevitch Anzonov, an 18-year-old of Chechen-Russian origin. In the speech, Emmanuel Macron made a statement that France would not take down the cartoon. Macron also declared war on Islamic separatism, which he believes has taken over some Muslim communities in France. On his Twitter post on November 1, 2020, said the French President said that he does not support cartoons that insult the Prophet, but he supports the ability to think, write and draw in his country because it is a form of freedom of speech. In France, the caricature of Prophet Muhammad has been associated with a proud secular heritage stretching back to the revolution. The ideology of secularism is represented through freedom in the context of the mass media. The freedom finally operates in the region construction of meaning about Islam, the Prophet Muhammad, and Muslims which is manifested in the form of mass cultural production in a number of media mass that can be represented in the form of text or images (Wazis, 2016).
His decision and opinion were decidedly controversial and backfired on his reputation. This is because Islam prohibits caricatures of the Prophet Muhammad. Muslims consider the caricature of the Prophet Muhammad to be offensive. According to the Muslim Forum cited in Yanuartha \& Sukmi (2016), there are several reasons why the caricature of the Prophet is prohibited, including; when the Prophet lived, no one drew him because Islam is very concerned about originality; avoiding the misunderstanding of worshiping idols; The Prophet's visualization opened up opportunities for blasphemy against his personality, and the issue of the authenticity and honesty of the image itself. An image based on imagination is essentially a lie. Wazis (2016) also discussed that the publication of the caricature of the Prophet Muhammad is considered an offense to Muslims. Thus, Emmanuel Macron's statement not to bring down the caricature of the Prophet Muhammad offended the Muslims around the world. As reported by Sutrisno (2020) in The Jakarta Post, the Indonesian Foreign Minister condemned the disrespectful remarks against Islam made by French President Emmanuel Macron that hurt the feelings of Muslims globally and fueled divisions among religions. The Russian newspaper, also reported that Chechen Mufti Salakh Mezhiyev stated Macron insulted the Prophet Muhammad, which means Macron was insulting prophets and religions. In addition, Turkish President Recep Tayyip Erdoğan 
protested Macron's statement insulting Islam by boycotting all French products, and several countries also boycotted (themoscowtimes.com, 2020).

This act of boycotting of French products was done by so many countries around the world due to how negatively this incident was portrayed in the news. As previously listed, news media around the world condemns the French President's action, so this research is interested to see the representation of French President Emmanuel Macron in the murder of Samuel Paty case from the French media's perspective where this case took place. Since France is a democratic country, news media has an essential role because the public news media can convey opinions and aspirations. The news media process includes conveying information and seeking the information so that the information produced by the media can be trusted. News media have a particular ideology in making news (van Dijk, 2002). Therefore, the alignments of one media with another on an issue can be different. The representation of Emmanuel Macron in the murder of Samuel Paty case also can be shown differently by various newspapers. This research tries to reveal the extent of negative representation of Emmanuel Macron, the France's President, in a selected newspaper of France, namely The Connexion France. This news label is chosen because it not only provides news in France, but also publishes them in the English language to enable people from other countries to be part of their intended audience

One of the most common and most effective method to analyse the alignments of a media towards specific issues through the use of language made by journalists is Critical Discourse Analysis (CDA). The CDA, according to Wodak \& Meyer (2001), is used to refer to the critical linguistics approach. This theoretical approach intends to find the larger discursive unit of the text as fundamental of communication. The critical linguistic approach considers institutional, political, gender, and media discourse to see the relation of struggle and conflict. Texts of news articles in particular have discursive practice. Extensive search identified a few records of previous studies that have analysed the news media using Wodak \& Meyer's (2001) five discursive strategies: referential/nomination, predication, argumentation, perception and intensification strategies. Previous studies tried to find evidence for all five discursive practices in their selection of news. Baykal (2009) analysed the discourse of the 2005 gentrification process in Turkey found one discursive strategy, while Hussein \& Ahmed (2020) found three discursive strategies to reveal how foreign policy goals, identities, and ideologies are communicated in EU discourse. Three studies took place in Indonesia; Purwanto (2017) found all five discursive strategies to analyse the Facebook posts of a major city mayor, Anggraeni \& Amalia (2020) found two discursive strategies to see the representation of Indonesia's Minister of Health regarding his conduct to address the Covid-19 pandemic, and Kurniawan \& Utami (2017) found two strategies to see how Indonesia's news represent the Indonesian President, Joko Widodo.

The overall state of this research body is difficult to pinpoint due to scarcity of studies that uses Wodak \& Meyer's (2001) discursive strategies to analyse the discursive practice in news. In critical discourse analysis, representation refers to the language used in a text to provide meaning to groups, social practices adopted by them, and events (Afzal, 2019). Only one study was found to have researched negative representation in news, but Utama \& Amalia (2019), who analysed how the United States' news represented the highly criticised Assad regime in Syria, used CDA in micro and macro levels, in other words, the linguistic structures and types of information content. Research that focuses on discursive strategy to reveal a representation of social actor is still scant. To fill this research gap, this present study used the nomination and predication discursive strategies to reveal the negative representation of the selected social actor, the French President, regarding his response to the cause of Samuel Paty's murder. In contrast to the previous studies, the researchers decided to use only these two discursive strategies because the researchers concentrated on the representation of a social actor. The recency of the case, which took place on October 2020, offers a novelty as most studies analysed old news or general representation of ideologies in media. Another novelty of this study lies in the research object, which is France's English online news. Moreover, majority of previous studies that carried out CDA on news referred to van Dijk's (2002) theory, thus this study also offers the research novelty of using Wodak \& Meyer's (2001) theory in this critical discourse analysis.

\section{Literature Review}

\subsection{Critical Discourse Analysis and Discursive Strategies}

This research uses Critical Discourse Analysis as an approach, and discursive strategy to analyse the data. According to Wang (2021), the focus of CDA is inequality and power relations in language, intending to explore the ideology implicit in the discourse. Since it relates to language, discourse analysis is called a study in applied linguistics that examines the use of language in interactions between speaker and listener or writer and reader (Anwar et al., 2020). Language plays an essential part in this process because it is used to prepare, accompany, motivate, and play any political action (Shah et al., 2021).

Utama \& Amalia (2019) discussed that CDA is one of the methods used by analysts to find the real identity. An object in discourse cannot exist alone since context determines the object's identity. Since this research tries to reveal the representation of an object in a specific context, which is Emmanuel Macron as an object in the context of Samuel Paty's murder case, CDA seems to be the proper method to use for this research. 
Gee \& Handford (2012) stated that Critical Discourse Analysis (CDA) contributes to critical social analysis that focuses on discourse and relations between discourse and other social elements, such as power relations, ideologies, institutions, social identities through language studies. According to Anwar et al. (2020), The CDA focuses on discourse structures that create, confirm, justify, reproduce, or challenge societal power relations and dominance. Merrita (2021) also discussed that Critical discourse analysis (CDA) is a method for revealing power in a text by analysing linguistic characteristics and ideology in the text is seen by using CDA. The order of discourse involves the order of the media; therefore, the order of discourse must consider the medium used to reproduce the discourse. There is always a purpose behind every news release made by the media. CDA used to see the ideology utilised by media to deliver the news (Bulan \& Kasman, 2018; Utama \& Amalia, 2019). Thus, Discursive practices carried out by the media include how news articles are produced by journalists and consumed by readers. The ideology conveyed by journalists through the use of language in news articles or what is called discourse may influence the ideology of readers.

A discourse contains a discursive practice that affects the ideological effect to produce an equal power relation between social classes, women and men, cultural majorities, and minorities through representing things or people's position (Fairclough \& Wodak cited in Zienkowski et al. 2011). Every discourse has a discursive practice that can be analysed using CDA to see how the discourse relates to social elements, such as the effect of ideology in the discourse that the media tries to share with readers. The discursive practice in a discourse can be analysed through the discursive strategies that the writers use in the discourse

According to Wodak \& Meyer (2016), discursive strategy means a less or more intentional plan of practice adapted to achieve a particular social, political, psychological, or linguistic goal. There are five discursive strategies. They are nomination, predication, argumentation, perspectivation, and intensification/mitigation (Wodak \& Meyer, 2001). The summarised five discursive strategies as shown in Table 1.

Table 1. A Selection of Discursive Strategies by Wodak \& Meyer (2001) (2001, p.73)

\begin{tabular}{cll}
\hline \multicolumn{1}{c}{ Strategy } & Objectives & Devices \\
\hline $\begin{array}{l}\text { Referential/ } \\
\text { nomination }\end{array}$ & $\begin{array}{l}\text { Construction } \\
\text { of ingroup and } \\
\text { outgroup }\end{array}$ & $\begin{array}{l}\text { - membership categorisation } \\
\text { - biological, naturalising, and } \\
\text { depersonalising metaphors and } \\
\text { metonymies } \\
\text { - synecdoches (pars pra tata, } \\
\text { Tatum pra pars) }\end{array}$ \\
Predication & $\begin{array}{l}\text { Labelling } \\
\text { social actors } \\
\text { more or less } \\
\text { positively or } \\
\text { negatively, }\end{array}$ & $\begin{array}{l}\text { - } \begin{array}{l}\text { attribution of positive and } \\
\text { negative traits } \\
\text { implicit and explicit predicate }\end{array} \\
\end{array}$ \\
\end{tabular}

\begin{tabular}{|c|c|c|}
\hline & $\begin{array}{l}\text { deprecatory or } \\
\text { appreciatively }\end{array}$ & \\
\hline Argumentation & $\begin{array}{l}\text { Justification } \\
\text { of positive or } \\
\text { negative } \\
\text { attributions }\end{array}$ & $\begin{array}{l}\text { topoi used to justify political } \\
\text { inclusion or exclusion, } \\
\text { discrimination, or preferential } \\
\text { treatment }\end{array}$ \\
\hline \multirow{2}{*}{$\begin{array}{l}\text { Perspectivation, } \\
\text { framing of } \\
\text { discourse } \\
\text { representation }\end{array}$} & $\begin{array}{l}\text { Expressing } \\
\text { involvement }\end{array}$ & \multirow{2}{*}{$\begin{array}{l}\text { reporting, description, narration, } \\
\text { quotation, of (discriminatory) } \\
\text { events or utterances }\end{array}$} \\
\hline & $\begin{array}{l}\text { Positioning } \\
\text { speaker's } \\
\text { point of view }\end{array}$ & \\
\hline $\begin{array}{l}\text { Intensification, } \\
\text { mitigating }\end{array}$ & $\begin{array}{l}\text { Modifying the } \\
\text { epistemic } \\
\text { status of the } \\
\text { proposition }\end{array}$ & $\begin{array}{l}\text { Intensifying or mitigating the } \\
\text { illocutionary force of } \\
\text { (discriminatory) utterances }\end{array}$ \\
\hline
\end{tabular}

Table 1 shows that the nomination strategy is a strategy on how the media uses linguistic devices. Those linguistic devices are proper names, synecdoche, or professional anthroponyms to refer to social actors in a discourse. Furthermore, the predication strategy is used to show what the social actors do. This strategy shows how the media labels the social actors based on what social actors do. Next, the argumentation strategy shows how the media argue against the issue in a discourse. The following strategy is the perspectivation strategy. This strategy shows how journalists bring up opinions or ideas from various points of view, either opinions or ideas that support or oppose the issue being discussed. The last discursive strategy by Wodak \& Meyer (2001) is the intensification/mitigation strategy. The strategy of intensification/mitigation is used to alter, add intensely, or limit, the act of illocutionary or discourse ideas. This strategy can show how the media deliver a clear, intensive, repetitive, or disguised message. Those five strategies are entirely fixed and can be used in part to be modified, adapted, and developed for each research object (Wodak \& Meyer, 2001). For example, to see the negative representation of Emmanuel Macron in the article regarding offending Islam, two discursive strategies, namely nomination and predication strategy, can be used to analyse the data.

According to Hegazy (2017), the way people and things are called and described in texts has ideological implications and reflections on power relationships and value judgments. The nomination strategy is used to analyse how the people and things are called in a discourse. In nomination strategy, proper name, synecdoche, metaphor, deictic and phobic expressions, collectives, and professional anthroponym can refer to social actors in a discourse (Kurniawan \& Utami, 2017; Mansouri et al., 2017). Synecdoche is a type of metonymy that involves the usage of a word or phrase in which a portion of something reflects the entire thing (Yule, 2014). In line with Yule (2014), Kurniawan \& Utami (2017) also discussed that synecdoche tries to draw attention to the social actor's position in which the action represents whole things. Another device in the nomination strategy is a 
professional anthroponym. According to Vieira (2006), one of the proper name categories is an anthroponym. An anthroponym is a name derived from ideology, knowledge, or professionals. This study refers to the name which attaches to the term of professionals.

This research uses the predication strategy to see how The Connexion France labels Emmanuel Macron, whether Macron was represented positively or negatively (Reisigl \& Wodak, 2001). Purwanto (2017) also stated that evaluative attributions of negative and positive traits in the linguistic form predicates realise predication strategy. Therefore, we can conclude that this predication strategy looks at the use of words attached to social actors, either positively or negatively. According to Rezaei et al. (2020), predicative adjectives, nouns, and noun phrases are prominent features of predicate structures used for positive/negative representation of others. Therefore, an explicit predicate is one of the devices for analysing predication strategy in a discourse. A predicate is the part of a sentence that includes the verb and provides information about the subject in grammar. The other device that we use to analyse predication is a presupposition. According to Yule (1996), the presupposition is the speaker's assumption in an utterance the speaker utters

\subsection{Critical Discourse Analysis on Media}

Media is a tool that can convey information widely, either printed or online; of course, it is because of technological advances. For example, newspapers usually only printed once a week now provide online portals and update information every day. As a result, the economy, society, and culture can be conveyed to the broader community through news media. News media portals is a prominent research object in Critical Discourse Analysis (CDA) studies. In CDA, the general definition of discourse is a language used in a written or spoken text with meaning and intentions. At the same time, the news media is a tool for delivering the discourse. Thus, the media discourse was born. Media discourse is a large-scale communication through a broadcast platform such as TV, Radio, Magazines, newspapers, and social media, whether spoken or written (O’Keeffe, 2015).

The focus of media discourse is a perspective on the very core of the process of mass communication. This media discourse study helps us to explain and evaluate the distribution of meaning in detail. The representations of the social world of media discourse are examined. It explores the kinds of connections that media texts create between people and the world. Furthermore, it investigates how context is constructed differently in various media texts, and therefore what different ways of seeing and thinking tend to be found there (Mathenson, 2015).An overview study about the use of Critical Discourse Analysis (CDA) has been conducted by Sahmeni \& Afifah (2019), who found that Van Dijk's CDA theory is the most widely used theory in media discourse studies. They discussed that CDA is a study that discursively investigates texts, interactions and social contexts, explores the relationship between language and ideology, and examines how dominant ideologies oppress. CDA can be used to analyse discourse in media since media plays an essential role in producing beliefs, prejudices and domination over social contexts because media tends to marginalise other people and misinterpret events. This is prominently visible in the results of Utama \& Amalia's (2019) study of how two Cable News Networks (CNN) articles negatively represented the Bashar Hafez al-Assad's long regime in Syria. The study used CDA in macro and micro levels and their research reveals three facts regarding CNN's writers. First, CNN uses negative lexical choices to describe Assad's regime. Second, CNN legitimises the US's arguments frequently by using verbal reactions in schematic analysis. Third, CNN tries to conceal another version of the truth.

CDA have mostly been utilised to analyse the media discourse of long-running issues around the world. Baykal (2009) used discursive strategy to analyse the discourse about the contradictions caused by the Romani people in the Sulukule region, İstanbul, Turkey, against the gentrification process that began in 2005. According to this research on the gentrification process in the region, the residents are trying to make their voices heard by opposing what they define as the unjust treatment of their human, social, cultural, and historical rights. Hussein \& Ahmed (2020) used three discursive strategies (e.g., nomination, predication, and argumentation strategies) to reveal how foreign policy goals, identities, and ideologies are communicated in EU discourse. They discovered that EU actors regard Iraq as a partner, close neighbour, and coworker. In conjunction, Iraq was trying to build an identity for the EU as an actor to bring about peace, democracy, and human rights. The study concluded that the EU is also trying to influence the perception of Iraq to follow suit. Additionally, Purwanto (2017) analysed several Facebook status uploads of Ridwan Kamil, Mayor of Bandung. The results showed that all of Wodak \& Meyer's discursive strategies were used by Ridwan Kamil in uploading statuses on Facebook, namely referential/nomination, predication, argumentation, perception and intensification strategies. Thus, Ridwan Kamil's status on Facebook has an implicit and explicit intention, and there are several aspects to Facebook status uploads that affect readers.

CDA studies that focused on specific cases are highly scarce. Anggraeni \& Amalia (2020) also analysed the representation of the Indonesian Minister of Health in handling the Covid-19 pandemic. Based on their research, Mr Terawan, as a Minister of Health, has negative attributive in The Jakarta Post because Mr. Terawan has performed poorly and is careless as a health minister in handling the Covid-19. Another study, Kurniawan \& Utami (2017) referred to Reisigl \& Wodak's (2001) discursive strategy on 
the representation of Joko Widodo as the Governor of Jakarta, the presidential candidate, and the President of Indonesia in The Jakarta Post. The study found that the news used nomination strategy to show that Joko Widodo's actions represent the Indonesian government and the positive predication strategies to present Jokowi's figure in all categories except the Corruption Eradication the Commission (KPK) issue. Therefore, the Jakarta Post does not fully support Joko Widodo in the KPK issue. Therefore, this present study on the specific case of French President's offense to Muslims around the world will contribute to this area of the CDA research.

\section{Method}

This research is qualitative in design because the researchers identify the problem based on explaining why something occurs, in this case a social phenomenon (Creswell, 2012; Alwasilah, 2000). The researchers analysed the data descriptively and presented the result in an explanation of words supported by data. The data for this research was news articles related to Emmanuel Macron on the murder of Samuel Paty case in The Connexion France news portal. The researchers analysed the data using the nomination and predication strategy theory by Wodak \& Meyer (2001). The researchers analysed the data byreducing the data into organised units, synthesising the data units, finding the pattern, selecting the crucial data units, and deciding what to present to the others (Moleong, Lexy 2004). Figure 1 shows the framework for how the researchers carried out this research.

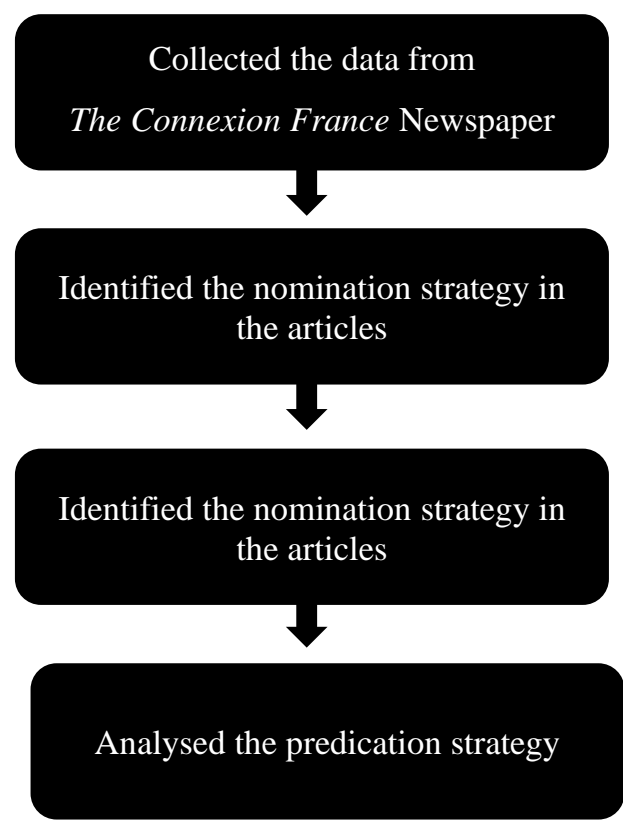

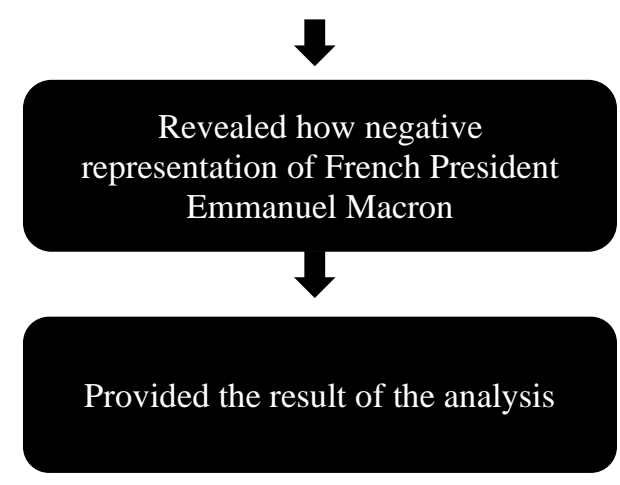

Figure 1. Methodological Framework

In the first step to analyse the data, the researchers collected the data from The Connexion France online news portal (www.connexionfrance.com). In collecting the data, the researchers looked for articles in The Connexion France using the keyword "Emmanuel Macron". According to Creswell (2012), the purposeful sample is used by researchers who intentionally select individuals and sites to learn or understand the central phenomenon. Thus, to select the data, the researchers used a purposeful sample related to Emmanuel Macron on the murder of Samuel Paty case. As a scope of limitation, the articles were chosen based on a specific period. The articles were published on October 18 , 2020, when President Macron's statement caused controversy for offending Islam until November 1, 2020, two weeks after the case occurred.

The researchers found thirty-two news articles in The Connexion France related to the "Emmanuel Macron keyword. However, there were four news articles related to Emmanuel Macron on the murder of Samuel Paty case. Thus, the four news articles from The Connexion France were chosen as the data in this research. The titles of the articles are:

a. French President: 'Immediate action' on Islamic terrorism, published on October 19, 2020. (https://www.connexionfrance.com/Frenchnews/Macron-promises-immediate-action-againstIslamic-terrorism)

b. French Muslim leaders pay respects to a murdered teacher, published on October 20, 2020. (https://www.connexionfrance.com/Frenchnews/French-Muslim-leaders-pay-respects-to-murderedteacher)

c. Call to boycott French products in Islamic caricatures row, published on October 25, 2020. (https://www.connexionfrance.com/French-news/Callto-boycott-French-products-in-Islamic-caricatures-rowafter-Macron-s-word-following-murder-of-Samuel$\underline{\text { Paty) }}$ 
d. French companies' not 'threatened' by the Middle East boycott, published on October 27, 2020. (https://www.connexionfrance.com/Frenchnews/French-companies-not-threatened-by-MiddleEast-boycott)

Afterwards, the researchers used the nomination strategy to see how The Connexion France refers to Emmanuel Macron linguistically in the selected articles. In the next step, the researchers used the predication strategy to see how The Connexion France labelled Emmanuel Macron, whether positive or negative. Then, researchers revealed how the negative representation of French President Emmanuel Macron on the murder of Samuel Paty case in The Connexion France based on the analysis. Finally, the researchers provided the result of the analysis.

\section{Results}

\subsection{Nomination Strategy on The Articles Regarding Emmanuel Macron Offends Islam in The Connexion France}

Based on the data analysis, there are nineteen nomination strategies regarding the murder of Samuel Paty case. The Connexion France used proper names, professional anthroponyms, synecdoche, and deixis as the nomination strategy. The nomination strategy used to refer to Emmanuel Macron in The Connexion France regarding the murder of Samuel Paty case is shown in Table 1.

Table 1. The Nomination Strategy Used by The Connexion France

\begin{tabular}{llc}
\hline \multicolumn{1}{c}{$\begin{array}{c}\text { Nomination } \\
\text { Strategy }\end{array}$} & \multicolumn{1}{c}{ Realisation } & Frequency \\
\hline Professional & The President & 4 \\
Anthroponyms & President Macron & 7 \\
& Macron & 4 \\
Proper Name & France & 3 \\
Synecdoche & He & 1 \\
Deixis & & $\mathbf{1 9}$ \\
\hline Total & &
\end{tabular}

Professional anthroponym is a word used to refer to a person by looking at the profession or work carried out by that person, such as "the scientist," "the teacher," "the YouTuber," and others. This research found professional anthroponym "The President" and "President Macron" used by The Connexion France. Those professional anthroponyms refer to Emmanuel Macron. The professional anthroponyms used by The Connexion France are shown in Excerpts 1 and 2 below.

"The President spoke at the defence council on Sunday night, two days after a deadly attack on a school teacher in France."

Excerpt 1_Proan-15

\begin{abstract}
"Across social media, calls have spread to boycott French products in protest, and numerous images of President Macron's face with footprints across it have also spread, alongside other caricatures."
\end{abstract}

Excerpt 2_Proan-3

France is a country with a long history of democracy. The President is responsible for running the country. The term "The President" in Excerpt 1 is used in articles by The Connexion France to characterise and report on Emmanuel Macron's acts as President of France. "President Macron" in Excerpt 2 is the other realisation of professional anthroponym used to focus on Emmanuel Macron as the President at that time.

Another device used by The Connexion France is the proper name "Macron". The word "Macron" refers to the French President to show the readers which person becomes the center of the text. Excerpt 3 is the example of data of proper name used by The Connexion France.

"Macron has asked the Interior Minister Gérald Darmanin to reinforce security in schools by the time students return to class after the Toussaint holidays on November 1."

Excerpt 3_Prome-18

The Connection France also used synecdoche as a nomination strategy to refer to Emmanuel Macron in the articles regarding the murder of Samuel Paty case in Excerpt 4 below.

"France would not renounce caricatures" of the Prophet Muhammed after the murder of teacher Samuel Paty."

Excerpt 4_Synec-12

Emmanuel Macron is the one who made the declaration about the cartoon of the Prophet Muhammad. However, in Excerpt 4 above, The Connexion France used the word "France" to refer to Emmanuel Macron because The Connexion France considers what Macron decided as President is a French decision. In other words, Emmanuel Macron represents France. Meanwhile, the deixis showed in The Connexion France to avoid repeating the name "Macron."

\subsection{Predication Strategy on The Articles Regarding Emmanuel Macron Offends Islam in The Connexion France}

Predication strategy is used to see how media attributes the social actor in discourse, whether positive or negative. Some devices can be used to analyse predication strategies, such as explicit predicate and presupposition. Some of the data analysis is shown below.

"French President Emmanuel Macron has promised "immediate action" against Islamic terrorism in France, speaking at a Sunday evening (October 18) meeting of' 'France's defence council."

Excerpt 5_Expre-16 
In Excerpt 5, the subject "President Emmanuel Macron" is given explicit attributive "has promised," which gives information that Emmanuel Macron has promised action against Islamic terrorism. Thus, by the explicit predicate, The Connexion France shows a positive attributive predication of Emmanuel Macron as a President who acts immediately against the Islamic terrorism issue in France.

Meanwhile, The Connexion France uses presupposition to show the negative attributive predication of Emmanuel Macron. The data that show negative attributive predication of Emmanuel Macron is shown in Excerpt 6.

"Photos of empty supermarket shelves have spread, purporting to show French products being stripped from sale in protest at Mr. Macron's words."

\section{Excerpt 6_Nepre-2}

The Connexion France has the assumption that photos of empty supermarket shelves show Emmanuel Macron's words caused French products to be stripped.

Based on predication strategy analysis, the researchers found that The Connexion France gave nine positives and eight negative attributive predications to Emmanuel Macron. Since this research tries to reveal the negative representation of Emmanuel Macron, the researchers have summarised how Emmanuel Macron was labelled negative by The Connexion France, as shown in Table 2 below.

Table 2. The labelling of Emmanuel Macron in The Connexion France

\begin{tabular}{ll}
\hline Nomination & \multicolumn{1}{c}{ Labelling } \\
\hline President & $\begin{array}{l}\text { Someone who caused a boycott call because of his } \\
\text { speech at the memorial ceremony in honour of slain } \\
\text { teacher Samuel Paty }\end{array}$ \\
& $\begin{array}{l}\text { Someone who declares not to take down cartoons of } \\
\text { the Prophet Muhammad, so French products are } \\
\text { facing boycott calls in some Middle Eastern } \\
\text { countries }\end{array}$ \\
\cline { 2 - 2 } & $\begin{array}{l}\text { Someone whose face was drawn with footprints by } \\
\text { the protestors }\end{array}$ \\
& $\begin{array}{l}\text { Someone whose words were criticised by President } \\
\text { Recep Tayyip Erdogan }\end{array}$ \\
\cline { 2 - 2 } & $\begin{array}{l}\text { Someone who declaration that France would not } \\
\text { renounce caricatures of the Prophet Muhammad and } \\
\text { it caused the boycott. }\end{array}$ \\
\cline { 2 - 2 } & $\begin{array}{l}\text { Someone who considered "needed treatment" for } \\
\text { "mental health" by Turkish President Recep Tayyip } \\
\text { Erdogan }\end{array}$ \\
\hline Macron & $\begin{array}{l}\text { Someone whose words are protested and causing a } \\
\text { boycott }\end{array}$ \\
\hline France & $\begin{array}{l}\text { A person who represents France in making decisions } \\
\text { would not renounce caricatures of the Prophet } \\
\text { boycott }\end{array}$ \\
\hline
\end{tabular}

The Connexion France referred to Emmanuel Macron as "President Macron." It gave negative attributive predication to Emmanuel macron as a person who declares not to take down cartoons of the Prophet Muhammad. Macron delivered this speech at the memorial ceremony in honour of slain teacher Samuel Paty. His speech caused a boycott call for France. President Recep Tayyip Erdogan criticised Macron and said Macron considered "needed treatment" for "mental health."

When The Connexion France uses the proper name Macron, the negative attributive predication is given to Emmanuel Macron. Emmanual Macron is considered as a person whose words are protested and causing a boycott. Emmanuel Macron is also labelled negative when he becomes a person who represents France in making decisions. For example, Macron would not renounce caricatures of the Prophet Muhammad after the murder of teacher Samuel Paty, and it caused French products to be facing a boycott.

\section{Discussion}

Based on the nomination and predication strategy analysis, the negative representation of French President Emmanuel Macron on the articles regarding the murder of Samuel Paty case in The Connexion France can be revealed. The Connexion France used four nomination strategies. They are deixis, proper names, professional anthroponyms, and synecdoche.

The findings of the research conducted by Baykal (2009), Sulukule people used the construction of the self and the other where the use of deixis 'we' vs 'them' as nomination strategy to showed that Sulukele people praised and emphasized the positive qualities of Romani people. Meanwhile, this research does not find any construction of the self and the other. It can happen because the data researched by Baykal (2009) are the interviews with people who are directly involved with the cases that occur, while in this study, the data researched were newspapers which have a function to report a case and were not directly involved with the case.

The other nomination strategy used by The Connexion France is the proper name "Macron". Anggraeni \& Amalia (2020) discussed that proper names show a person who becomes the center of the text. The Connexion France also uses the proper name to focus Macron as a center in discourse and avoid ambiguity about whom The Connexion France is talking. Professional anthroponym becomes the most frequent nomination strategy used by The Connexion France. According to Kurniawan \& Utami (2017), the professional anthroponym puts forward someone's professionalism instead of the other side in their research. It is also used to describe and report someone's action regarding his job. In Kurniawan \& Utami's (2017) research, Professional Anthroponym shows Jokowi's professional change from being governor, presidential candidate, and as Indonesian president. This also shows there are changes in 
the job carried out by Jokowi. However, in this study, professional anthroponyms did not show any changes like what happened to Jokowi in Kurniawan \& Utami's (2017) research. The professional anthroponym is used to show that Emmanuel Macron is a French President when the case of Samuel Paty murder happened.

Synecdoche was also used as a nomination strategy to indicate that Emmanuel Macron is someone who represents France. Kurniawan \& Utami (2017) found that synecdoche draws attention to the social actor's position as the President and shows his every action represents the action that the government and country take. Through synecdoche "France", Emmanuel Macron becomes the part for the whole (Koslow, 2015). This expands Emmanuel Macron's position as the person who represents "the French people".

The predication strategy was used to see the negative attributive predication of social actors. This study detected eight negative attributive predications of Emmanuel Macron in the articles of the murder of Samuel Paty case published by The Connexion France. Many negative attributes are attached to Emmanuel Macron when The Connexion France uses professional anthroponyms to refer to Emmanuel Macron. Comparing the results with Kurniawan \& Utami's (2017) research, the label attached to a social actor in his role as a professional can turn negative or positive depending on the case faced by the social actor. The Connexion France gives the negative attributive predicate to President Macron as someone who gave a speech at a memorial service in honour of the murdered teacher Samuel Paty. Furthermore, he declared not to take down the Prophet Muhammad's cartoon, which caused French products to face calls for boycott in several Middle Eastern countries. Therefore, the negative predicate attached to President Macron in the articles shows a negative representation. The Connexion France seems to show the consequences of the French President's actions that harm France itself. In addition, a negative attributive was given to Emmanuel Macron as President of France, as a person whose words were criticised by President Recep Tayyip Erdogan and considered "needed treatment" for "mental health". When the nomination Strategy was realised as "Macron" and "France," The Connexion France only gave one negative attributive predication to Emmanuel Macron. The Connexion France uses an explicit predicate when giving the positive label to Emmanuel Macron. On the other hand, The Connexion France mostly uses presuppositions to give a negative label to Emmanuel Macron. Hussein \& Ahmed (2020) in his research also found that presupposition is used to label social actors. Hussein explained that the use of Presuppositions is important in terms of triggering readers agreement to the content presented. It means, The Connexion France uses presuppositions to show the negative label of Emmanuel Macron and leaves the readers to have their own interpretation of the assumptions made by The Connexion France. However, Kader (2016), who researched to analyse
Anti-Islamization and Anti-immigration Discourse, found that adjectives and words associated with predicate nouns negatively affect social actors. In contrast, this research found explicit predicates and presuppositions used to give negative predicates to social actors. The findings of predicates and presupposition mean that the media's negative attributions do not always use the same way.

The results of this research reveal the negative representation of Emmanuel Macron in the issue of Murder of Samuel Paty in The Connexion France online newspapers. Utama \& Amalia's (2019) research also shows the negative representation of social actors, namely Assad's long reign in Syria, in CNN online newspapers. However, the way they analyse data that reveals negative representation of social actors in online newspapers is different from ours. Utama \& Amalia (2019) uses Van Dijk's CDA theory which is the most widely used theory to reveal the representation of social actors (Sahmeni \& Afifah, 2019), by seeing at the negative lexical choices used by the author to describe the Assad regime, and also see the use of verbal reactions in schematic analysis. While the research we conducted used two discursive strategies theory by Wodak \& Meyer (2001), where the article was analysed by seeing at how social actors were referred to linguistically in the article and how predication strategy was used to label social actors. This research shows that the discursive practices created by the media can show the representation of social actors.

This research shows that nomination and predication strategy can reveal the representation of social actors. By nomination strategy, the choice of words that refer to social actors has its meaning and function such as showing who is the focus or who is being discussed in the text, showing one's professional identity, and avoiding repetition of words in the text. It is also important for English learners to be able to determine the choice of the right words in writing so that there is no ambiguity or misunderstanding. The predication strategy through explicit predicate and presupposition is used to describe the labels attached to Emmanuel Macron. This is expected to provide an overview of how language can be used to label social actors, either positive or negative. Thus, the analysis of this predication strategy can be a reference for language learners in labeling someone in a text.

The negative representation of the French President Emmanuel Macron on the murder of Samuel Paty case shows that The Connexion France believes that Emmanuel Macron's speech was the cause of harm to France, the loss is getting calls for a boycott of French products. The negative representation is revealed through the labeling of Emmanuel Macron. The labels attached to Emmanuel Macron in articles either using an explicit predicate or a presupposition lead to the harm suffered by France because of Emmanuel Macron's controversial speech. This research also finds out how The Connexion France gives a negative label to Emmanuel Macron, by mostly used presuppositions. The Connexion 
France seems does not want to give a negative label directly to Emmanuel Macron, therefore The Connexion France makes presumptions that make readers should conclude for themselves.

This research contributes knowledge in the field of Critical Discourse Analysis (CDA), especially in research on the representation of social actors in online newspapers using two discursive strategy theory by Wodak \& Meyer (2001), namely nomination and predication strategy. This research also provides an overview of how to analyse data using the theory of discursive strategy to reveal the representation of social actors. This study only focuses on two strategies, but further researchers can add three other discursive theories to review more details about the representation of social actors.

\section{Conclusion}

This study addressed the research gap of how social actors are represented in news media. The research novelty of this study is its use of discursive strategies rooted in Wodak and Meyer's theory rather than the dominantly used van Djik's theory. Based on the analysis of nomination and predication strategies, this study reveals that the negative representation of Emmanuel Macron in his response to the cause of Samuel Paty's death meant that France's news did not hide the fact that Emmanuel Macron has made a speech that led to a boycott of French products, which is a disadvantage for France. However, the Connexion France more often used presuppositions to label Emmanuel Macron negatively. It shows that The Connexion France does not give a negative label to Emmanuel Macron explicitly, but the Connexion France made the assumptions that let readers make their own interpretations. This research shows that the discursive practice made by media can be analysed through language use and the result of the analysis can reveal the representation of social actors. This research not only contributes to fill the research gap of social actor's media representation, but also demonstrated the benefits for future English language researchers in analysing how language is used in news media.

\section{References}

Afzal, N. (2019). Discursive Strategies and Media Representation of Conflicts. International Journal of $\begin{array}{lll}\text { English } \quad \text { Linguistics, } & 9(2), & 1 .\end{array}$ https://doi.org/10.5539/ijel.v9n2p1

Alwasilah, A. C. (2000). Pokoknya Kualitatif. Pustaka Jaya.

Anggraeni, Y., \& Amalia, R. M. (2020). The Representation of Health Minister in Handling Covid-19 in Indonesia : a Critical Discourse Analysis. Celtic: A Journal of Culture, English Language Teaching, Literature, \& Linguistics, 7, 208-215.

Anwar, A., Laraswati, A., \& Ridhani, R. (2020). Critical Discourse Analysis in Media Studies: A Review
Research on Its Application in Indonesian Context. Elsya : Journal of English Language Studies, 2(1), 32 36. https://doi.org/10.31849/elsya.v2i1.3615

Baykal, N. (2009). The Discursive Construction of Ethnic Identity: Sulukule Case, Turkey Nazl1. The Linguistics Journal, September, https://doi.org/10.5040/9781474295741.ch-009

121.

Bulan, A., \& Kasman, K. (2018). Critical Discourse Analysis of Ahok's Speech in Kepulauan Seribu. Transformatika: Jurnal Bahasa, Sastra, Dan Pengajarannya, 2(1), 50 https://doi.org/10.31002/transformatika.v2i1.555

Creswell, J. W. (2012). Educational research: planning, conducting, and evaluating quantitative and qualitative research. University of Nebraska-Lincoln.

Gee, J. P., \& Handford, M. (2012). The Routledge handbook of discourse analysis. Routledge.

Hegazy, H. M. M. (2017). A Critical Discourse Analysis of Naming and Predication in Western News Coverage of the Egyptian January 25 and June 30 Protests. Occasional Papers in the Development of English Education, 63(2), 209-260. https://doi.org/10.21608/opde.2017.88205

Hussein, A. S., \& Ahmed, M. H. (2020). Representation, Attribution and Perspectivation in EU Diplomatic Discourse Addressed to Iraq. International Journal of Linguistics, Literature and Translation (IJLLT), 3(11), 55-67. https://doi.org/10.32996/ijllt

Kader, N. A. (2016). A Critical Analysis of Anti-Islamisation and Anti-immigration Discourse: The Case of the English Defence League and Britain First. May, 24113123.

Koslow, S. (2015). Writing Race in Haiti's Constitutions: Synecdoche and Negritude in Post-Revolutionary Haiti [Baylor University]. http://hdl.handle.net/2104/9456

Kurniawan, E., \& Utami, A. D. (2017). The Representation of Joko Widodo's Figure in The Jakarta Post. Indoneisan Journal of Applied Linguistics, 6(2), 341350 .

Mansouri, S., Biria, R., Mohammadi Najafabadi, M., \& Sattar Boroujeni, S. (2017). Nomination and Argumentation Strategies in Oratory Discourse: The Case of an English Sermon. SAGE Open, 7(2). https://doi.org/10.1177/2158244017702425

Mathenson, D. (2015). Media Discourses: Analysing Media Texts. Open University Press.

Merrita, D. (2021). Nationalism ideology: Critical discourse analysis of Joko Widodo's speech in Indonesian presidential election. Celtic: A Journal of Culture, 
English Language Teaching, Literature, \& Linguistics, $8(1)$, $112-125$

https://doi.org/10.2219/celtic.v8i1.16474

Moleong, Lexy, J. (2004). Metodologi Penelitian Kualitatif (Edisi Revi). Remaja Rosdakarya.

O'Keeffe, A. (2015). Media and discourse analysis. In 'Media and Discourse Analysis', in Gee, J. \& Handford M. (eds), The Routledge Handbook of Discourse Analysis. (pp. 441-454). Routledge. https://doi.org/10.4324/9780203809068.ch31

Purwanto, Y. (2017). Discursive Strategies on Ridwan Kamil's Status Update: a Critical Discourse Analysis. Humaniora, $8(2), \quad 153$. https://doi.org/10.21512/humaniora.v8i2.3893

Reisigl, M., \& Wodak, R. (2001). Discourse and discrimination: Rhetorics of racism and antisemitism. Routledge.

Rezaei, F., Samar, R. G., \& Kiany, G. (2020). Exploring Identity Representation Strategies in English and Persian Political Discourse. Teaching English Language, 14(1), 1-29.

Sahmeni, E., \& Afifah, N. (2019). Using Critical Discourse Analysis (CDA) in Media Discourse Studies: Unmask the Mass Media. REiLA: Journal of Research and Innovation in Language, 1(2), 39-45. https://doi.org/10.31849/reila.v1i2.2764

Shah, M. I., Ahmad, S. A., \& Danishs, A. (2021). Controversies in Political Ideologies: A Critical Discourse Analysis of Speeches of Indian and Pakistani Premiers on Pulwama Incident. Register Journal, 14(1), 43-64. https://doi.org/10.18326/rgt.v14i1.43-64

Sutrisno, B. (2020). Indonesia condemns France for "disrespectful" statement on Islam. Www.Thejakartapost.Com. https://www.thejakartapost.com/news/2020/10/30/ind onesia-condemns-france-for-disrespectful-statementon-islam.html

themoscowtimes.com. (2020). France's Macron 'the No. 1 Terrorist in the World,' Chechen Mufti Says. https://www.themoscowtimes.com/2020/10/27/france s-macron-the-no-1-terrorist-in-the-world-chechenmufti-says-a71864

Utama, G. N., \& Amalia, R. M. (2019). Negative Representation of Assad's Regime in CNN Online Article. OKARA: Jurnal Bahasa Dan Sastra, 13(1), 65. https://doi.org/10.19105/ojbs.v13i1.2262

van Dijk, T. A. (2002). Political discourse and political cognition. In P. Chilton \& C. Schaffner, (Eds.), Politics as text and talk: Analytic approaches to political discourse. John Benjamins Publishing Company.

Vieira, R. (2006). Computational Processing of the Portuguese Language. 7th International Workshop.

Wang, Y. (2021). A Critical Discourse Analysis of News Reports on Covid-19 in People's Daily and The New York Times Analisis Wacana Kritis Laporan Berita tentang Covid-19 di People' s Daily dan The New York Times. Jurnal Ilmu Pengetahuan Dan Teknologi Komunikas, 23(1), 49-62.

Wazis, K. (2016). Konstruksi kebebasan media massa barat sebagai budaya populer: Analisa terhadap berita dan karikatur nabi saw di majalah charlie hebdo. Al'Adalah, 18(2), 259-282. http://ejournal.iainjember.ac.id/index.php/aladalah/article/view/326

Wodak, R., \& Meyer, M. (2001). Methods of Critical Discourse Analysis. SAGE Publication Ltd.

Wodak, R., \& Meyer, M. (2016). Methods of Critical Discourse Studies (Third). SAGE Publications Ltd.

Yanuartha, R. A., \& Sukmi, S. N. (2016). Makna Karikatur Interpretatif Mabi Muhammad pada Cover Majalah Charlie Hendo (Analisis Semiotika Roland Barthes Cover Depan Majalah Perancis Charlie Hebdo Edisi 19 September 2012). Cakrawala, September, 1-41. https://ejournal.uksw.edu/cakrawala/article/view/78

Yule, G. (1996). Pragmatics. Oxford University Press. https://doi.org/10.1002/jmv

Yule, G. (2014). The Study of Language. Cambridge University Press. http://bibliotecavirtual.unad.edu.co:2048/login?user= proveedor $\&$ pass $=$ danue $0 \mathrm{a} 0 \&$ url=http://bibliotecavirtu al.unad.edu.co:2051/login.aspx?direct=true $\& d b=$ nleb $\mathrm{k} \& \mathrm{AN}=387929 \&$ lang $=$ es \& site $=\mathrm{eds}-$ live \&ebv=EK\&ppid=Page-_ -42

Zienkowski, J., Östman, J.-O., \& Verschueren, J. (2011). Discursive pragmatics. Benjamins. 